\title{
Near-Facility Environmental Monitoring Quality Assurance Project Plan
}

\section{S. M. McKinney}

Waste Management Federal Services Inc., Northwest Operations

Date Published

June 1999

Prepared for the U.S. Department of Energy

\section{FLUOR DANIEL haNFORD, INC. \\ P.O. Box 1000}

Richland, Washington

Hanford. Management and Integration Contractor for the

U.S. Department of Energy under Contract DE-ACO6-96RL13200 


\section{RELEASE AUTHORIZATION}

Document Number:
HNF-EP-0 $538-4$
Document Title:
Near-Facility Environmental Monitoring Quality Assurance Project:Plan

\section{This document, reviewed in accordance with DOE}

Order 241.1, "Scientific and Technical Information Management," and DOE G 241.1-1, "Guide to the Management of Scientific and Technical Information," does not contain classified or sensitive unclassified information and is:

\section{APPROVED FOR PUBLIC RELEASE}

\section{Chistimin \\ c. WiTlingham \\ Lockheed Martin Services, Inc. \\ Document Control/Information ciearance}

Reviewed for Applied Iechnology, Business Sensitive, Classified, Copyrighted; Export Controlied, Pattent, Personal/Private, Proprietary, Protected CRADA, Tracienark, Unclíssified controlied Nuclear Information.

LEGAL OISCLAIMER. This report was prepared as an 'account of work sponsored by an agency of the United states Government. Neither the United States Government nor any agency thereof, not any of their employees, nor any of their contractors, subcontractors or their employees, makes any warranty, express or implied, or assumes any legal liability or responsibility for the accuracy, completeness, or any third party's use or the results of such use of any information, apparatus, product, or process disclosed, or represents that its use would not infringe privately owned rights. 'Reference herein to any specific commercial product, process, or service by trade name, trademark, manufacturer, or otherwise, does not necessarily constitute or imply its endorsenent, reconmendation, or favoring by the United states Government or any agency. thereof or its contractors or subcontractors. Thie views and opinions of authors expressed herein do not necessarily state or reflect those of the United States Government or any agency thereof. This report has been reproduced from the best avail lable copy. Printed in the United States of America. 
HNF-EP-0 $0538-4$

NEAR-FACIIITY ENVIRONMENTAL MONITORING QUALITY ASSURANCE PROJECT PLAN

Prepared by:

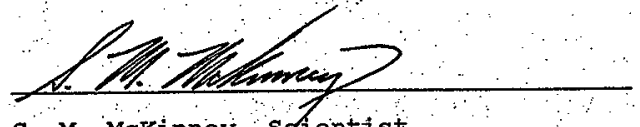

Date: $5.25 \cdot 99$

s. M. Mckinney, scientist

Environmental Monitoring Investigations

Waste Management Federal Services, Inc.

Northwest Operations

Reviewed and

Approved by:

J. J. Dorian, Manager

Date: $5 / 27 / 99$

Environmental Monitoring \& Investigations

Waste Management Federal Services, Inc.

Northwest Operations

Approved by:

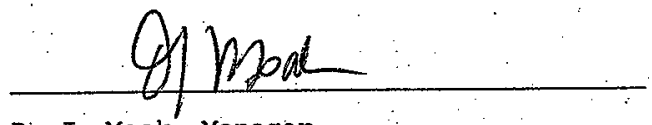

Date: $6-4-99$

D. J. Moat, Manager

Environmental Services Division

Waste Management Federal Services, Inc.

Northwest operations

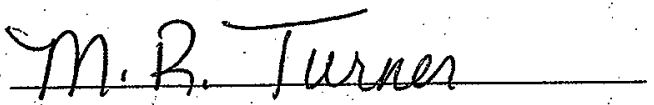

Date: $\sigma / 4 / 99$

M. R. Turner, Lead

Quality Assurance

Waste Management Federal Services, Inc.

Northwest operations

i 
HNF-EP-0538-4

This page intentionally left blank. 


\section{QUAIITY ASSURANCE PROJECT PIAN}

\section{s. M. Makinney}

\section{ABSIRACT}

This Quality Assurance Project Plan addresses the quality assurance requirements for the activities associated with the preoperational and near-facility environmental monitoring performed by waste Management Federal Services, Inc., Northwest Operations and supersedes $H N E^{\prime}-H P-0538-3$. This plan applies to all sampling and monitoring activities performed by Waste Management Federal services, Inc. Northwest operations in implementing near-facility environmental monitoring at the fanford site.

This Quality Assurance Project Plan is required by U.S. Department of Energy Order 5400.1 (DOE 1988a) as a part of the Environmental Monitoring PIan (DOE-RL 1997) and is used to define: $=$

- Environmental measurement and sampling locations used to monitor envifonmental contaminants near active and inactive facilities and waste storage and disposal sites

- Procedures and equipment needed to perform the measurement and sampling.

- Erequency and analyses required for each measurement and sampling location

- Minimum detection level and accuracy.

- Quality assurance components

- Investigation levels. 
$H N F-E P-0538-4$

Near-facility environmental monitoring for the Hanford site is conducted in accordance with the reguirements of U.S. Department of Energy Orders 5400.1 (DOE 19882), 5400.5 (DOE 1990), 5484.1. (DOE 1981), and 5820.2A ( $D O E 1988 \mathrm{~b}) \%$ and $D O E / E H-0173 T$ (DOE 1991)." It is Waste Management Federal Services, Inc., Northwest operations' objective to manage and conduct activities at the Hanford site in a cost-effective and environmentaliy responsible manner that is in compliance with the letter and spirit of these regulations and other environmental regulations, statutes, and standards. 
HNF-EP-0538-4

CONTENTS

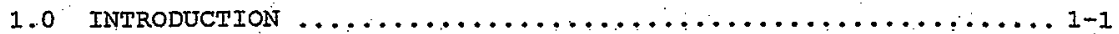

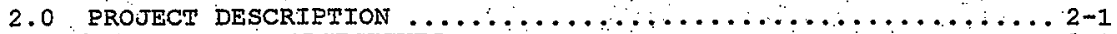

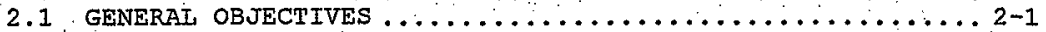

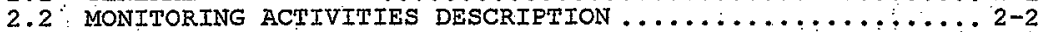

2.3 APPIICABILITY TO WASTE MANAGEMENT EEDERAI SERVICES,

INC.

QUALITY ASSURANCE PROGRAM .................... 2-3

3.0 PROJECT ORGANIZATION AND RESPONSIBIIITIES $\ldots \ldots \ldots \ldots \ldots \ldots \ldots$

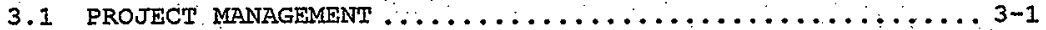

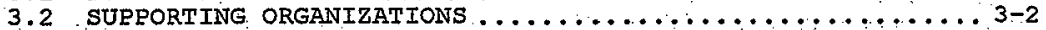

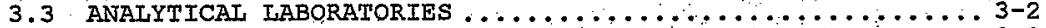

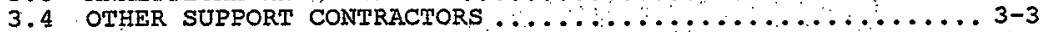

4.0 QUALITY ASSURANCE OBJECTIVES EOR MEASUREMENTS . . . . . . . . . 4-1

4.1 ANATYTES OF INTEREST AND ANAIYTICAL MBTHOD SEIECTION $\because \ldots 4-1$

4.2 CONTRACTUAI QUANTITATION IIMITS AND RANGES EOR

ANATYTICAT

$\therefore \quad$ PRECISION AND ACCURACY . . . . . . . . . . . . . . . . $4-1$

4.3 RERRESENTATIVENESS, COMPIETENESS, AND COMPARABILITY . . . . 4-2

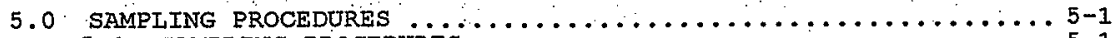

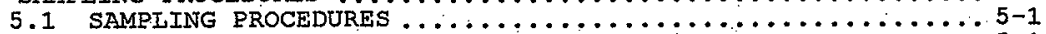

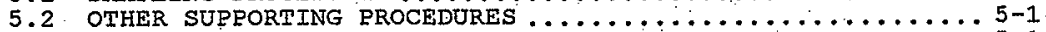

5.3 PROCEDURE APRROVAJS AND CONTROI .................. 5-1 5.3.1 Waste Management Eederal Service, Inc. Procedures. 5-1 5.3.2 Participant Contractor/Subcontractor Procedures... 5-1

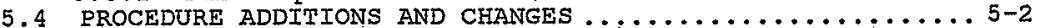

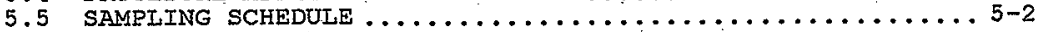

6.0 SAMPLE CUSTODY .......................... $6-1$

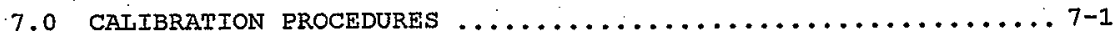

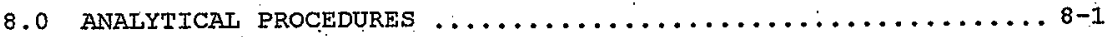

9.0 MONITORING AND REPORTING CRITERIA ................. 9-1

10.0 DATA REDUCTION, VAIIDATION, AND REPORTING ........... 10-1 10.1 : DATA REDUCTION AND DATA PACKAGE PREPARATION ........ 10-1

10.2 VAIIDATION . . . . . . . . . . . . . . . . . . . . . . $10-1$

10.3 FINAI REVIEW AND RECORDS MANAGEMENT CONSIDERATIONS ... 10-2

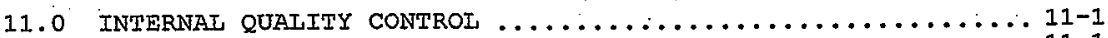

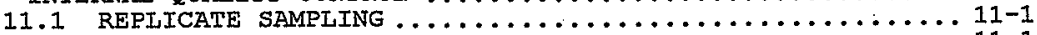

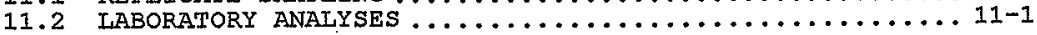

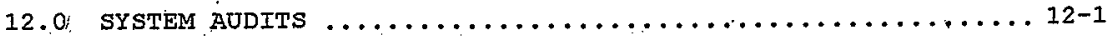

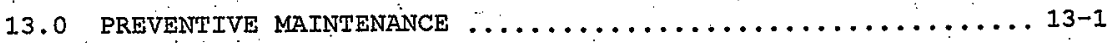

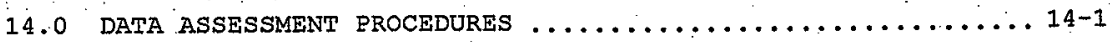


HNF-EP-0 $0538-4$

CONTENTS (cont)

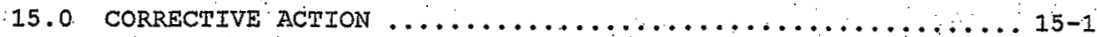

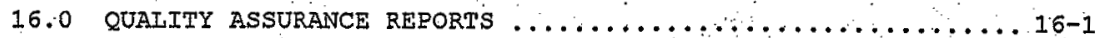

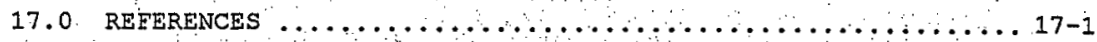

\section{IIST OF TABIJS}

4-1 Rreferred Analytical Methods . . . . . . . . . . . . . . . $4-3$

4-2 Supporting Procedures for the Near-Facility

Environmental Monitoring Program .................. $4-5$ 


\section{IIST OE TERMS}

BH $\dot{I}$

CERCIA

CER

CBRCS

DOE

DOE RI

EMP

EPA

EEMP

HAS

LITW

MDC

PHMC

PNNNL

$Q A$

QAPJP

QC

RC

RL

SPSP

WDOH

WMINW
Bechtel Hanford, Inc.

Comprehensive Environmental Response

Compensation and Iiability Act of 1980

Code of Federal Regulations

Component Based Recall Calibration system

U.S. Department of Energy

Richland Operations office

Environmental Monitoring Plan

U.S:- Environmental Protection Agency

facility effluent monitoring plan

Hanford Analytical Services

low-level waste

minimum detectable concentrations

project Hanford Management Contract

Pacific Northwest National taboratory

quality assurance

quality assurance project plan

quality control.

Radiological Control.

U.S. Department of Energy, Richland operations office.

Site Environmental Surveillance Program

Washington State Department of Health

Waste Management Eederal Services, Inc.

Northwest Operations 
HNF-EP-0538-4

\section{This page intentionally left blank:}




\subsection{INTRODUCTION}

The U.S. Department of Energy (DOE) Order 5400.1, General Environmental Protection Program (DOE 1988a), required DOE sites to prepare an environmental monitoring plan (EMP): "The revised Environmental Monitoring Rlan, DOE/RI 91-50, Revision 2 (DOE-RL 1997), was issued on November 9, 1997.

According to the guidance provided in DOE Order 5400.1 (DOE 1988a), each DOE site, facility, or activity that uses, generates, releases, or manages significant quantities of hazardous materials shall provide a written EMP. This EMP must identify and discuss two major activities: effluent monitoring and environmental surveillance.

This quality assurance project plan (QAPJP) addresses the quality assurance. ( $Q A)$ implementation of the near-facility environmental monitoring surveillance program as part of the overall EMP. 
HNF-EP-0 $0538-4$

This page intentionally left blank. 


\subsection{PROJECT DESCRIPTION}

\subsection{GENERAI OBJECTIVES}

Near-facility environmental monitoring provides facility-specific monitoring to protect the environment adjacent to facilities under the responsibility of the Project Hanford Management Contract (PHMC) or Bechtel Hanford Inc. (BHI), to ensure compliance with PHMC and BHI requirements and local, state, and federal environmental regulations.

The objectives of near-facility environmental monitoring are to evaluate the following:

- Compliance with DOE, the U.S. Environmental Protection Agency (EPA), the Washington state Department of Ecology (Ecology), the Washington state Department of Health (WDOH), and internal PHMC and BHI environmental radiation protection requirements and guides

- Performance of radioactive waste confinement systems

- Trends of radioactive materials in the environment at and adjacent to nuclear facilities and waste disposal sites.

specifically; near-facility environmental monitoring is developed to:

- Monitor inactive, existing, and new low-level waste (IIW) disposal sites to assess both radiological and nonradiological hazards (DOE Order 5820.2A).

- Determine the effectiveness of effluent treatment and controls in reducing effluents and emissions (DOE/EH-0173T and $\mathrm{DO} / \mathrm{EV} / 1830-\mathrm{T} 5$ ).

- Detect and quantify unplanned releases (DOE/EH-0173T) [Title 40. Code of Federal Regulation (CER) Part 302] [Washington. Administrative Code (WAC) 173-303-145] (DOE Orders 5000.3A and 5484.11 .

- Monitor fugitive emissions and diffuse sources from contaminated areas for compliance with the "National Emission standards for Hazardous Air Pollutants" (NESHAP) (40 CFR 61), (DOE/EH-0173T), TOXiC Air Emissions Inventory (40 CER 265, Subparts:AA and B13), state operating Permit Program ( 40 CFR. 70), and Source Registration (WAC 246 and 247).

- Monitor all surplus facilities before and during decontaminating or decommissioning (DOE order 5820.2A).

- Monitor new and existing sites, processes, and facilities for potential impacts and releases (DOE Orders 5400.1 and 5484.1 , and DOE/EH-0173T).

- Monitor and assess radioactive contamination and potential exposure to employees and the public (DOE Orders 5400.1, 
5400.5 and 10 CER 835 Occupational Radiation Protection).

The purpose and justification for near-facility environmental monitoring is contained in HNF-RRO-454, Inactive Waste sites and HNFPRO-455, Solid Waste Management.

The primary justification for near-facility environmental monitoring includes the following:

- Near-facility environmental monitoring provides a level of insurance to PHMC that the effluent and contamination controls for the various facilities and waste sites are effective.

- Near-facility environmental monitoring monitors a diversity of operations, activities, and programs managed by severai different PHMC contractor and BHI organizations. Accordingly, program direction and integration for nearfacility environmental monitoring activities are needed to ensure consistency, technical quality, and cost effectiveness.

- A secondary aspect of near-facility environmental monitoring is additional insurance beyond that provided by the occupational Health and Safety Program that it is acceptable to work on site and for visitors to safely tour the site.

It is the objective of WMWW to manage and conduct activities at the Hanford site in a cost-effective and environmentaliy responsible manner that is in compliance with the letter and spirit of applicable environmental statutes, regulations, and standards. Near-facility environmental monitoring shall monitor fugitive emissions and diffuse sources from radioactively contaminated areas. " In addition, WMNW shail ensure that activities are conducted to protect employeos, the public, the environment, and government property.

This QAPJP identifies the requirements and specifies the procedures used to implement near-facility environmental monitoring.

Responsibilities are defined for those WMNW personnel involved in environmental monitoring. WMNW personnel shall use this QAPJP to ensure that near-facility environmental monitoring is performed in a consistent manner.

\section{2:2. MONITORING ACTIVITIES DESCRIPTION}

The specific near-facility environmental monitoring activities performed by WMW are defined in HNE-PRO-454, Inactive Waste sites, HNF-PRO-455, Solid Waste Management, and WMNW-CM-004, WMNWW Environmental Monitoring, and generaliy fall into one or more of the following four categories:

- Monitoring of inactive and active waste storage and disposal sites as well as unplanned release sites

- Preoperational monitóning of new or modified facilities that have the potential to adversely impact the environment 
- Monitoring of operating or standby facilities,

- Monitoring of facilities in the process of demolition or remediation.

The monitoring scope for these categories includes the collection of ambient air, water, sediment, aquatic vegetation, soil, biota, external radiation measurements, and radiological surveys.

\subsection{APPLICABIIITY TO WASTE MANAGEMENT HEDERAI SERVICES, INC. QUAIITY ASSURANCE RROGRAM}

This QARjP applies specifically to the sampling and analysis activities, and monitoring performed for all near-facility. environmental monitoring activities conducted by WMNW. This plan is subordinate to the Quality Assurance Program PIan for Project Hanford Management Contract Work, WMNW-QAPP-001.

This QAPJP is prepared in accordance with the guidance of Interim Guidelines and specifications for Preparing Quality Assurance Project PIans, QAMS-005/80 (EPA 1983), and "Quality Assurance Methods, "40 CFR 61, Appendix B, Method 114, as required by the Environmental Regulatory Guide for Radiological Effluent Monitoring and Environmental Surveillance, DOE/EH-0173T. It describes the means selected to implement the overall $Q A$ program requirements defined in the HNE-MP-599, Project Hanford ouality Assurance Program Description. The implementing procedures, plans, and instructions are appropriate for the control of near-facility environmental monitoring, which requires compliance. with DOE, EEA, state, and local requirements.

The QAPJP uses a matrix of procedural resources from facility or Hanford Site manuals used in near-facility environmental monitoring. This QAPJP shall be reviewed and updated as required when changes are made in near-facility environmental monitoring. Distribution and revision control of this plan shall be in compliance with HNE-MP-599, Project Hanford Quality Assurance Program Description.

Review/approval personnel indicated on the title page of the document and other individuals designated by Environmental Monitoring and. Investigations (EM\&I) shal1 have distribution and revision control. Plans and procedures referenced in the QAPJP are available on request for regulatory review. 
This page intentionaliy left blank. 


\subsection{PROJECT ORGANIZATION AND RESEONSIBIIITIES}

\subsection{RROJECT MANAGEMENT}

Environmental Monitoring and Investigations within the Environmental Services Organization of Waste Management Federal Services, Inc., Northwest operations has the responsibility for specifying near-facility environmental monitoring requirements. Responsibilities of key personnel are described below.

- Near-Field Moritoring. The Near-Field Monitoring team within Environmental Monitoring and Investigations has the responsibility to plan, direct, and verify near-facility environmental monitoring at PHMC and BHI facilities; unplanned release sites, and associated active and inactive waste storage and disposal sites as required to ensure compliance to enviromental requirements.

Near-Field Monitoring acts as the technical liaison between PHMC facilities, other DOE contractors, regulators, and other interested parties. Near-Field Monitoring also provides technical support for operational environmental. sampling and analysis. Near-Field-Monitoring performs trend analysis and prepares annual near-facility environmental monitoring reports for distribution to PHMC and BHI facilities, DOE contractors; regulators, and other interested parties. Near-Field Monitoring assigns sample numbers and identification numbers for each sample point. Near-Field Monitoring maintains the permanent records of: near-facility environmental monitoring samples. Near-Field Monitoring also ensures that the QAPJP and associated documentation are updated.

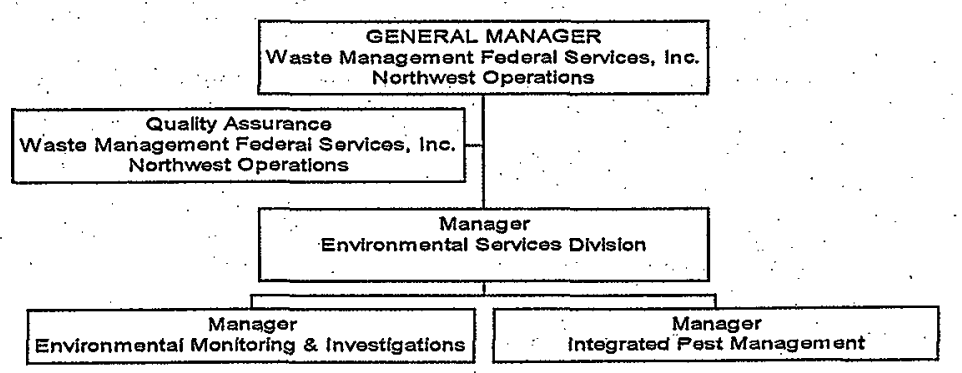

- Integrated Pest Management. Integrated Pest Management contains two organizational functions, Pest Control and Vegetation Management. These two functions work closely with Near-Facility Monitoring in identifying and controlling the spread of contamination through biological vectors. In: February 1999, an integrated biological control program was developed under the direction of DOE/RT with Technical Authority being assigned to Fluor Daniel Hanford, Inc and Project management being assigned to Dyncorp pri-Cities Services, Inc. 
- Radiological Control/site surveillance. The site support Services Radiological Control Group has the responsibility to provide sampling and monitoring support as defined in near-facility environmental monitoring. The Bechtel Hanford, Inc., Radiological Moritoring and Environmental. support Group has the responsibility to provide radiation surveys of inactive waste sites and facilities under its control.

\subsection{SUPPORTING ORGANIZATIONS}

- racility Manager. The facility manager has the responsibility to maintain the facility in an environmentaliy safe condition, be responsive to environmental problems or concerns raised about the facility, and provide corrective action to these problems of concerns.

- quality Assurance. Provides quality-engineering support to meet procurement control, document approval, surveililance, and auditing needs.

- Air \& water services. Air \& water services has the responsibility to oversee and verify the environmental radioactivity and chemical emission monitoring program at PHMC facilities as required to enșure compliance with environmental regulations.

- Procurement. The procurement organization obtains services and/or contracts in accordance with purchase requisitions, purchase orders, drawings, contracts, specifications, or instructions used to define requirements for a purchase.

- Environmental Integration. These personnel provide guidance in interpretation of all regulations and coordination with pertinent regulatory agencies and establish and maintain the environmental series of procedures, HNE-PRO-450 through HNEPRO -462 .

- Analytical Services. Provides data package validation as requested by EM\&I.

\subsection{ANAIYTICAL IIABORATORIES}

Analytical samples will be transported to an approved PHMC participant contractor or subcontractor laboratory for radiological and/or chemical analysis. For participant contractors or subcontractors, applicabie quality requirements of this QAPjP shall be invoked as part of the approved applicable work order, letter of instruction, or procurement document. Iaboratories are to submit their analytical methods and internal $Q A$ Program to Hanford Analytical Services: (HAS) for review and approval before use.

At the direction of EM\&I, laboratories may be procured for split (performance audit) sample analysis. Participant contractor or 
subcontractor laboratories will be subject to source surveillance with Quality systems participation, in compliance. with HNF-MP-599, Project Hanford QuaIity Assurance Program Description and HNF-PRO268, Procurement Control and/or WMNW-ECM-001, Procurement Manual:

\subsection{OTHER SUPPORT CONTRACTORS}

The EMEI program may procure the services of other subcontractors to support any or all of the activities addressed by this QAfjP. Such activities shall be in compliance with PHMC approved QA plans and/or procedures, subject to the controls of HNE-MP-599, Project Hanford Quality Assurance Program Description and/or miN-QAM-001, Quality Assurance Manual. 
This page intentionally left blank. 


\subsection{QUALITY ASSURANCE OBJECTIVES FOR MEASUREMENTS}

The $Q A$ objectives for measurements generally applicable to nearfacility environmental monitoring under the purview of this QAPJP are related primarily to the following:

- Defining appropriate methods for sampling and analysis for the required analytes of interest

- Defining quantitation limits and values for analytical precision and accuracy appropriate for the purposes of all near-facility environmental monitoring.

- Defining data representativeness, completeness, and comparability in terms applicable to near-facility environmental monitoring.

Detailed discussions of the analytes of interest and analytical methods are provided in Table 4-1. Specific data quality needs for individual investigations shall be addressed at the time of the need. other measurement considerations, accuracy requirements, units, and data recording/reporting protocols far instruments supporting nearfacility environmental monitoring and other types of special monitoring investigations shall be specified in the applicable procedures discussed herein and in the laboratory statements of work. The statement of work are as follows: statement of Work for services Provided by the Waste Sampling and Characterization Facility for Effluent and Environmental Monitoring Program During Calendar Year 1999, HNF-EP-0835-5 (Diediker 1999), and Pacific Northwest Laboratory (PNL) Letter of Instruction Number 8H000-96-IOI-001.

\subsection{ANALYTES OF INTEREST AND ANAIYTICAL METHOD SELECTION}

Table 4-1 identifies potential analytes of interest and corresponding analytical reference methods for operational environmental samoling and monitoring at the Hanford Site. The list of analytes specifies reference methods selected from the appropriate EPA and DOE guidance documents. (See notes $a, d, e, f, g$, and $h$ of Table 4-1.) Where options have been suggested or implied, the more reliable methods have been selected.

The 222-s Laboratory typicaliy performs radiological analyses of all samples submitted and the Waste sampling and Characterization Facility (WSCE) laboratory performs analyses of radioactive and nonradioactive constituents in air, liquid, soil, vegetation and aquatic soil and vegetation associated with near-facility environmental monitoring. Pacific Northwest Laboratories reads the activity on the thermal luminescent dosimeters.

\subsection{CONTRACTUAI QUANTITATION IIMITS AND RANGES FOR ANALYTICAT PRECISION AND ACCURACY}

The performance of the analytical laboratory or laboratories providing support to near-facility environmental monitoring shall be subject to ERA-established method and analyte-specific quantitation limits and ranges for precision and accuracy (EPA 1972, ERA 1977). These parameters are presented as target values that PHMC and the 
proposed laboratory must adjust and/or confirm and accept before the final approval of an assoclated subcontract; work order, or statement of work.

\subsection{RIFRESENTATIVENESS, COMEIETENESS, AND COMPARABILITY}

The specifications of location and intervals in WMNW-CM-004, WMNW Environmental Monitoring address qualitative goals for data representativeness. Completeness objectives for near-facility environmental monitoring shall require that the contractually or procedurally established requirements for the precision and accuracy be met for at least 90 percent of the requested determinations on an annual basis for each laboratory conducting analyses. This means that precision and accuracy for all operational environmental monitoring data shall be at least 90 percent effective, accurate, and precise overall.

Fallure to meet this criterion shall be documented in data summary reports and shall be considered in validation process. corrective action measures using specific procedures shall be initiated by EMaI, HAS or $Q A$, as appropriate. Approved analytical procedures shall require the use of the reporting techniques and units" consistent with the $E_{P A}$ reference methods listed in Table 4-1 to facilitate data-set comparability in terms of precision and accuracy. 
Table 4-1. Preferred Analytical Methods:

\begin{tabular}{|c|c|c|c|}
\hline $\begin{array}{l}\text { Analytical } \\
\text { Category }\end{array}$ & $\begin{array}{l}\text { Analyte of } \\
\text { Interest }\end{array}$ & $\begin{array}{c}\text { Standard EPA } \\
\text { Reference Method }\end{array}$ & $\begin{array}{l}\text { Analytical } \\
\text { Method }\end{array}$ \\
\hline \multirow{3}{*}{$\begin{array}{l}\text { Ions/Anions } \\
\therefore \\
\because\end{array}$} & Nitrate & $352.1^{d}$ & $\mathrm{~b}$ \\
\hline & Nitrite. & $354.1^{d}$ & $\bar{b}$ \\
\hline & $\begin{array}{l}\text { Ph/Total } \\
\text { Dissolved } \\
\text { Solids (TSD) }\end{array}$ & $\begin{array}{r}9045^{\mathrm{d}} \\
\therefore \quad \therefore\end{array}$ & $\mathrm{b}$ \\
\hline \multicolumn{4}{|l|}{ Radionuclides } \\
\hline & Gross Alphak & $9310^{2}$ & $\mathrm{~b}$ \\
\hline & Gross Beta & $9310^{2}$ & $b$ \\
\hline & $\begin{array}{l}\text { Uranium } \\
(238,239,240)\end{array}$ & $00-07^{2}$ & $\mathbf{b}$ \\
\hline$\because$ & $\begin{array}{l}\text { Urantum } \\
233,234\end{array}$ & $00-07^{\mathrm{T}}$ & b \\
\hline & Uranium 235 & $00-07^{1}$ & $\mathrm{~b}$ \\
\hline & $\begin{array}{l}\text { Plutorium } \\
\{238,239,240\} \\
9 \quad\end{array}$ & $\begin{array}{r}00-07^{\mathrm{e}} \\
\vdots \\
\vdots\end{array}$ & $\therefore$ \\
\hline & Plutonium 241 & $00-07^{8}$ & $\mathbf{b}$ \\
\hline & $\begin{array}{l}\text { Americium } \\
241,243\end{array}$ & $A M-01^{\circ}$ & $\mathrm{b}$ \\
\hline$\therefore$ & $\begin{array}{l}\text { strontium } \\
89 / 90\end{array}$ & $\therefore \quad \mathrm{SR}-05^{\mathrm{I}}$ & $\bar{b}$ \\
\hline & Tritium & $707^{n}$ & $b$ \\
\hline . & Technetium 99 & BC-186 & $\mathrm{b}$ \\
\hline & Cesium 137. & $\therefore \mathrm{NA}$ & $b$ \\
\hline & Cesium 134 & $\mathrm{NA}$ & $\mathrm{b}$ \\
\hline & Cesium 135 & NA & $\bar{b}$ \\
\hline V & Todine 129 & NA & $\mathrm{b}$ \\
\hline & Cerium 144 & NA & $\bar{b}$ \\
\hline$\because \vdots$ & Carbon 14 & $\mathrm{NA}$ & $\mathrm{b}$ \\
\hline & Ruthenium 103 & NA & $\mathrm{b}$ \\
\hline & Ruthenium 106 & NA & $\mathbf{b}$ \\
\hline. & Selenium & NA & $\mathrm{b}:$ \\
\hline$\quad \ldots$ & Cobalt $60 / 58$ & NA & $\mathrm{b}$ \\
\hline
\end{tabular}




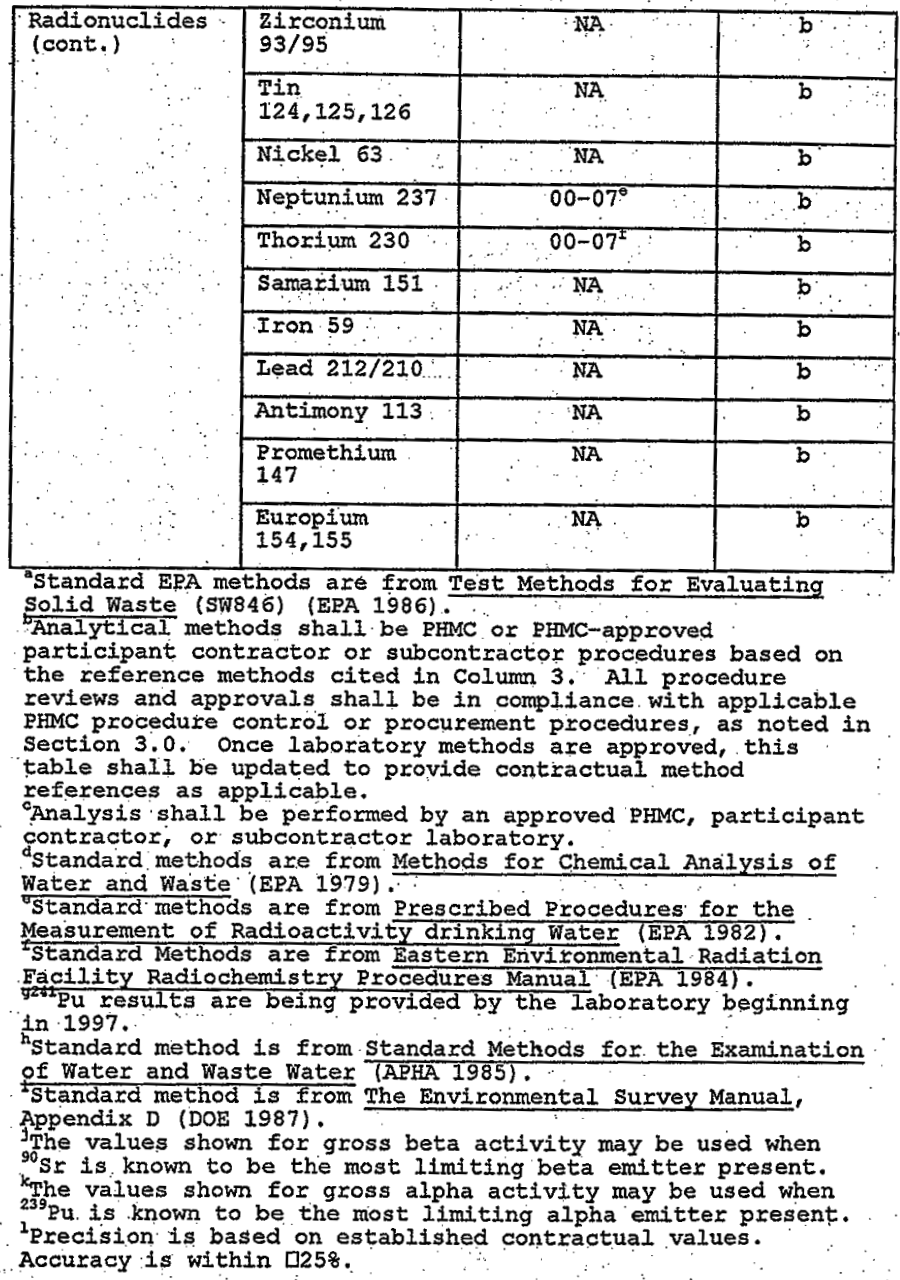


Table 4-2. Supporting Procedures for the Near-Facility Environmental Monitoring Program.

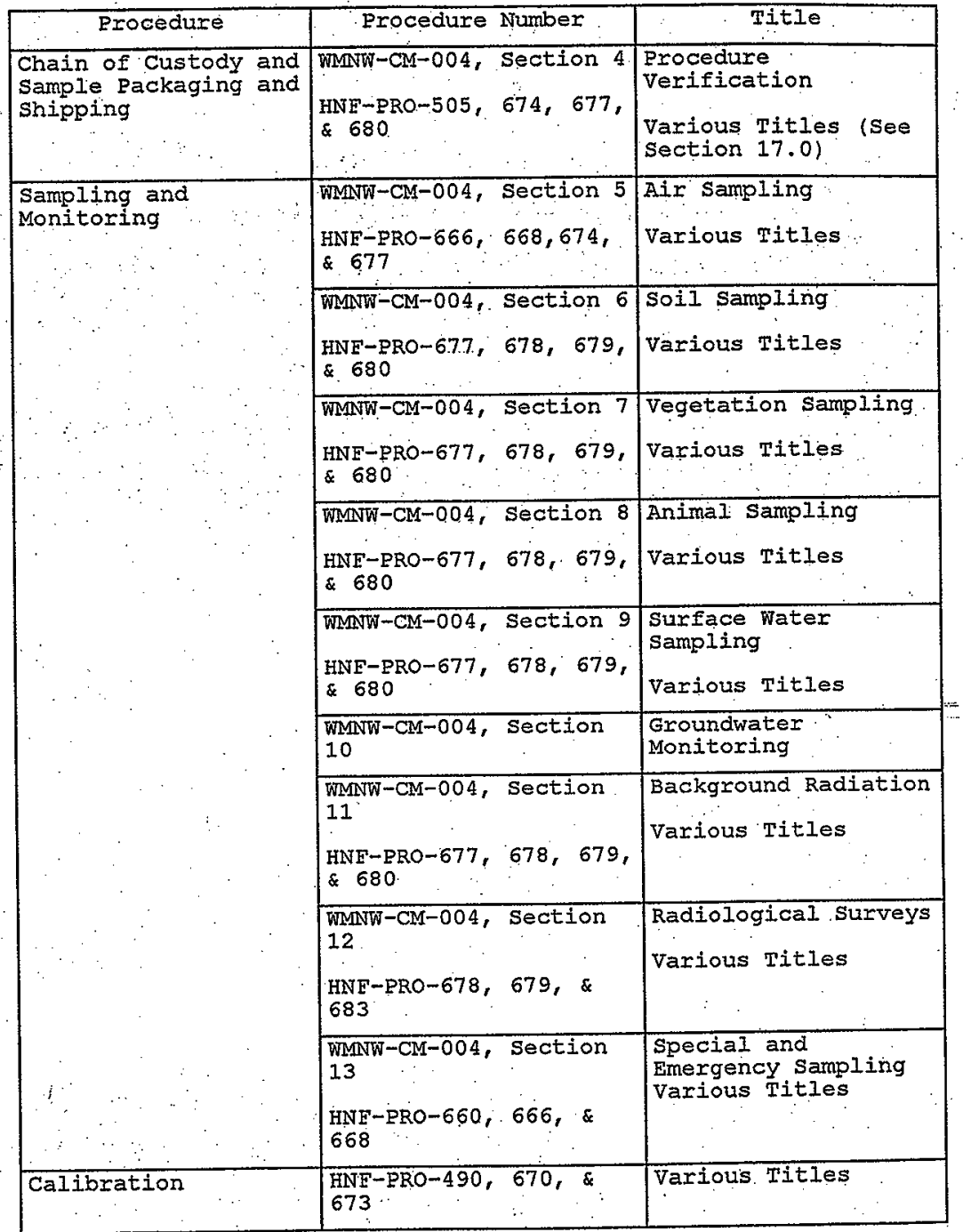


HNF-EP-0538-4

This page intentionally left blank. 


\subsection{SAMPIUING PROCEDURES}

\subsection{SAMPIING PROCEDURES}

Sampling activities, equipment, material, and containers will be subjected to field screening (i.e., radiological survey and quality control check of transportation documentation) for radioactivity. This screening shall be in compliance with the requirements governing radiation permits to ensure that samples are transported only to appropriately equipped and Iicensed laboratories. All environmental monitoring sampling conducted in support of near-facility environmental monitoring will be performed in a manner that provides representative samples of radioactive materials in near-field environmental media from operations at the Hanford site.

\subsection{OTHFR SUPPORTING PROCEDURES}

Except for the analytical chemistry procedures. specified in Table 4-1, procedures to be used to support Environmental Monitoring and Investigations program activities directly are presented in Table 42 , cross referenced to their source documents and the types of activities they typically will support.

\subsection{PROCEDURE APRROVAIS AND CONTROI.}

\subsubsection{Waste Management Federal Services, Inc. Northwest Operations Procedures}

The WMNW and PHMC procedures that may be used to support nearfacility, environmental monitoring sampling and monitoring activities are referenced in Table 4-2. Latest approved versions of all referenced procedures shall apply in all cases. Selected manuals include WMNW Environmental Monitoring, HNF-PRO-505, Radiation Protection and associated procedures, BHI-EH-02, Rev. O, Environmental Requirements, Section 7.0, HNF-MP-599, Project Hanford Quality Assurance Program Description, and HNE-PRO-268, Procurement Control. All procedures are available on request at the direction of EM\&I.

\subsubsection{Participant Contractor/Subcontractor Procedures}

As noted in section 3.4, participant contractor and/or subcontractor services may be procured with the concurrence of the EM\&I manager. Such procurement shall be subject to the applicable requirements of HNF-MP-599, Project Hanford Quality Assurance Program Description, and. HNE-PRO-268, Procurement Control; and/or WMNW-QAM001 , Quality Assurance Manual, and. WMNW-PCM-001, Procurement Manual.

Whenever such services require procedural controls, use of WMaN procedures, or submittal of contractor procedures for WMNW review and approval before use, such requirements shali be included in the procurement document or work order. In addition to submitting analytical procedures, analytical laboratories shall be required to submit the current version of their $Q A$ plans. 


\subsection{FROCEDURE ADDITIONS AND CHANGES}

Additional procedures or changes to existing procedures that are necessary to accommadate unforeseen field situations may be authorized in accordance. with section 4.0, "Program Verification" of WMNW-CM-004, WMNW Bnvironmental Monitoring.

\subsection{SAMPLING SCHEDULE}

A Routine operational Environmental Monitoring schedule is issued annually. It includes the schedule of radiation surveys, sampling to be performed, and sampling frequency.

The Near-Field Monitoring team prepares the radiation survey and sampling schedules.. The Near-Field Monitoring team shall approve any changes to the schedule, including temporary or one-time deviations, in accordance with WMNW-CM-004, WMNW Environmental Monitoring. 


\subsection{SAMPLE CUSTODY}

All samples obtained during Environmental Monitoring and. Investigations program activities shall be controlled as reguired by WMNW-CM-004, WMNW Environmental Monitoring, Section 4, "Program Verification." These requirements apply as soon as the sample is introduced to the sample container.

other requirements for specific samples are given in WMNW-CM-004, WMNW Environmentil Monitoring. These requirements shall ensure the maintenance of sample integrity and identification from receipt through completion of the analytical process.

Requirements for returning residual sample materials after analysis shall be defined in the procurement documentation or work orders to subcontractor or participant contractor laboratories. Analysis results shall be traceable to original samples through unique sample numbers or identification codes. All analyses results shall be controlled as permanent project quality records, as required by HNE-MP-599, Project Hanford Quality Assurance Program Description (and associated procedures) and HNE-PRO-208, Records Management General (and associated procedures). 
This page intentionally left blank. 


\subsection{CAIIBRATION PROCEDURES}

Calibration of all WMNW measuring and test equipment, whether in the existing inventory or purchased for near-facility environmental. monitoring, shall be controlled as required by HNF-MP-599, Project Hanford Quality Assurance Program Description.

Calibration and maintenance are the controling factors in this system.

Routine operational checks for WMN field equipment shall be as defined in internal: WMNW procedures; similar information shall be provided within WMNW-approved participant contractor or subcontractor procedures. The sampling and monitoring equipment used in this activity is controlled by the Component-Based Recall Calibration system (CBRCS) or another WMN-approved system.

Calibration procedures can be made available under the direction of the EM\&I manager. 
This page intentionally left blank. 


\subsection{ANALYTICAI RROCEDURES}

Analytical methods or procedures based on the reference methods identified in section 4.0 shall be selected or developed and approved before use in compliance with appropriate PHMC procedure, work order, and/or procurement control requirements (Section 5.3.2):

All participating contractors or subcontractors quality-affecting records shall be retained in compliance with. HNE-MP-599, Project

Hanford Quality Assurance Program Description. All such documents will be made available on request at the direction of EM\&I. 
This page intentionally left blank. 


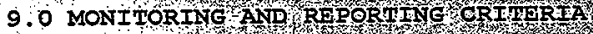

The criteria for near-facilty environmental sampling, monitoring, and reporting are identified 1 HNF-PRo -454 , Inact Waste Sites, HNF-PRO-455, Solid Waste Management and HNF-PRO-457, Environmental Requirements Evaluation. 
This page intentionaly left blank. 


\subsection{DATA REDUCTION, VAIIDATION, AND REPORTING}

\subsection{DATA REDUCTION AND DATA PACKAGE PREPARATION}

Analytical laboratories shall be responsible for preparing both a report summarizing the analysis results and a detailed data package : The data package shall include information necessary to perform data validation to the extent indicated by the minimum requirements.

Data reporting requirements and data package content shali comply with the appropriate requirements of Test Methods for Evaluating solid Wastes, SW-846-1. (EPA 1992). These requirements shall be defined in work ordex or procurement documentation, subject to wMN review and approval as noted in section 4.2 .

Data packages shall be prepared in legible, reproducible, format; any changes must be made as single-line corrections in black, nonsoluble ink; changes must be initialed and dated.

other supporting information (such as initial calibration data, reconstructed ion chromatographies, spectrograms, and raw data) need not be-included in the submittal of individual data packages unless specifically requested by EM\&I.

The analytical laboratory shall retain all sample data and make it available for system or program audits at the request of WMNW, EPA, the U.S. Department of Energy, Richland operations office. (RI), WDOH representatives, or other regulatory agencies. The analytical laboratory shall retain such data through the duration of the authorization work order or for the period of their contractual statement of work, when it shall be turned over to WMNW or the contract administrator for archiving.

The analytical laboratory's QA manager shall review and approve the completed data package before submittal for validation. The requirements of this section shall be included in procurement documentation or work orders, as appropriate, in compliance with the standard WMNW procurement control procedures referenced in section 3.0 .

\subsection{VALIDATION}

The EMaI shall verify and validate completed data packages for radioactive operational environmental samples when requested. Analytical Services (AS) may. be requested to validate the completed data packages for hazardous or nonradioactive operational

environmental samples. Alternative sources: may be used as directed by EM\&I. Regardless of the source of validation services, validation requirements shall be defined with WMN-approved data validation procedures, which at a minimum shall require the following oc checks. 
For organic analyses, validation reports shall be prepared documenting $Q C$ checks as recommended in Laboratory Data validation Functional Guidelines for Evaluating Organics Analyses (EPA 1988 a).

For inorganic analyses, validation reports shall be prepared documenting $\mathrm{QC}^{\mathrm{C}}$ checks as recommended in Laboratory Data Valiclation Functional Guidelines for Evaluating Inorganics Analyses (EPA $1988 \mathrm{~b})$.

Validation procedures for radionuclides and other types of analyses shall include requirements for $Q C$ checks with similar levels of detail.

The level of confidence in the data resulting from the radiological analyses shall be estimated by analyzing blanks and spiked pseudosamples ( $\mathrm{EPA}$-designáted environmental measurement Iaboratory program) and by comparing the resulting concentration estimates to the known concentrations in those samples. The precision of radionuclide analytical results shall be reported as a range, a variance, a standard deviation, a standard error, and/or a confidence interval. "When selecting the data to be considered, outliers shall be excluded from the data only after investigation confirms that an error has been made in the sample collection, preparation, measurement, or data analysis process. As new data are received, they shall be compared to earlier data.

\subsection{FINAL REVIEW AND RECORDS MANAGEMENT CONSIDERATIONS}

The EM\&I will perform a final technical review of validation reports and supporting analytical data packages before submittal to the customer or inclusion in reports or technical memoranda. $\because$ Records management practices shall comply with HNE-MP-599, Project Hanford Quality Assurance Program Description: 


\subsection{INTERNAI QUALITY CONTROT.}

In general, analytical samples shall be subject to in-process quality control measures in both the field and the laboratory. The following minimum field quality control requirements apply to rout ine operational envixonmental monitoring samples. These requirements are adapted from those recommended by the EPA office of Enforcement, as well as those of the research and development contractor, where practical. Radiological Control uses procedures described in HNFPRO -505 .

\subsection{SAMELE QUATTTY CONTROT}

The quality control of field samples is maintained using one or more of the following methods as appropriate:

- Replicates repeated but Independent determinations of the same sample.

- Blanks: a sample of the carrying agent (gas, liquid, or solid) normally used to selectively measure a material of interest that is subjected to the usual analytical procedures process to establish a baseline of background value. This value is then used to adjust or correct the routine analytical results.

- Duplicates: single sample taken, aliquoted alternately into two sets of sample containers for duplicate analysis.

- Splits: single sample taken, aliquoted alternately into two or more sets of sample containers, but will be sent to different laboratories; one sample will be sent to the primary laboratory, the others will be sent to an independent laboratory.

- Spiked Sample: a normal sample of material (gas, liquid, or solid) to which a known amount of some substance of interest is added. Spiked samples are used to check on the accuracy of a routine analysis of the recovery efficiency of an analytical method.

\subsection{IABORATORY ANAIYSES}

Near-facility environmental monitoring depends on the data received from analytical laboratories. A procedure verification program is vital to environmental sample analyses. This procedure verification effort consists of analytical standards, adherence to written sampling procedures, procedural audits, and record keeping.

The following companies whose services are controlled in accordance with procedures in HNE-MP-599, project Hanford Quality Assurance Program Description, provide laboratory support to nearfacility environmental monitoring sampling program:

1. Offsite Iaboratory. This laboratory analyzes selected 
environmental media samples.

2. Froject Hanford Management contract. The analytical laboratories analyze air samples and the sediment, water, and aquatic vegetation samples from the liquid disposal sites and the environmental soil, vegetation and biota samples.

3. Radiation Standards and Engineering at Pacific Northwest National Iaboratory. The Calibration Laboratory at PNNI reads, tests, calibrates, and packages the thermoluminescent dosimeters.

4. Internal raboratory qualty control programs AII

laboratories maintain internal quality control programs that address practices: such as:
a. Routine calibration of counting instruments
b. Routine source and background counts
c. Routine yield determination of radiochemical procedures
d. Replicate analyses to check precision
e. Analysis of quality control standards
f. Analysis of reagent blanks to verify chemical purity.

5. National standards Program. The laboratories performing the environmental analyses use standards traceable to the National Institute of Standards and Technology, when available, to ensure the accuracy of radionuclide determinations.

Other requirements specific to laboratory analytical equipment calibration are included in section 7.0. The minimum requirements of this section shall be invoked in procurement documents or work orders in compliance with standard PHMC procedures as noted in section 5.3.2. The statement of work should be reviewed by the laboratory to ensure that the laboratory is capable of performing the work. 


\subsection{SYSTHM AUDITS}

2 Adats shal be performed fo verify the quality of operation of one ormore elerients of the total measur in the sense intended by QAMS-005\%80 (FPA 1983), system audits involve a qualtative onsite evaluation of laboratories (or other organizational elements of the measurement system for compliance with established $Q A$ program and procedure requirements. This also includes audits of individual facility sampling programs against those requirements in near-facility environmental monitoring:

The appropriate organization shall perform system audits; system audit requirements shall be implemented through the use of HNE-MP599, Project Hanford Quality Assurance Frogram Description, and HNFPRO-651, Surveillance. Additional performance or system audits shaII be conducted if specificaliy required by near-facility environmental monitoring, as a consequence of corrective action requirements, or if requested by QA, RI, EPA, or WDOH.

Any discrepancies observed while evaluating performance audit results or during system audit surveillance activities that cannot be corrected immediately to the satisfaction of the investigator shald require a response and appropriate corrective action. AII discrepancies shal be documented.

Environmental Monitoring and Investigations activities may be evaluated as part of a PHMC facility or program audit in accordance with HNF-MP-599, Project Hanford Quality Assurance Program Description, and HNE-PRO-246, Management Assessments, and HNF-ERO651, Surveillance and/or as part of a WMNW program audit in accordance with WMNW-QAM-001, Quality Assurance Manual, WMNW-QAD-001, Quality Assurance Procedures. 


\section{This page intentionally left blank:}




\section{3:0 PREVENTIVE MÁINTHENANCE}

Measurement and testing equipment used in the field and laboratory that directly:affect the quality of the analytical data shall be subject to preventive maintenance measures that ensure measurement systems have minimal downtime and can perform reliable measurements: Field equipment maintenance instructions shall be as defined by the approved procedures governing equipment use.

Iaboratories shall be responsible for performing or managtng the maintenance of their analytical equipment; maintenance requirements, spare parts lists, and instructions shall be included in individual methods or in laboratory $Q A$ plans; subject to WMN review and approval as noted in sections 3.3 and 4.2 . 
This page intentionaliy left blank. 


\subsection{DATA ASSESSMENT PROCEDURES}

Data from environmental media sampling and monitoring shall be assessed as required by near-facility environmental monitoring and appropriate statistical evaluation techniques that may be referenced therein. The laboratory first shall compile the analytical data; and validate it in compliance with the requirements established in the approved Statement of Work: 
This page intentionaliy left blank. 


\subsection{CORRECTIVE ACTION}

Requests for corrective action required as a result of surveillance or audit activity shall be documented and dispositioned as required by HNE-MP-599, Project Fanford Quality Assurance Program. Description, and HNE-PRC-298, Control of Nonconforming Items, HNEPRO-52, Corrective Action Management, HNF-PRO-651, Surveiliance, HNEPRO-652, Corrective Action Request and WMNW CM-004 WMNW Environmental Monitoring.

The EM\&I responsibilities for corrective action follow -up and resolution are contained in WMN-CM-0.04, WMNW Environmental

Monitoring. Other measurement systems; procedures, or plan corrections that may be required as a result of routine review processes shall be resolved as required by governing procecures or shall be referred to EM\&I for resolution. Copies of all surveillance nonconformance, audit, and corrective action documentation shall be maintained on completion or closure by the surveillance/auditing organization. The project $Q A$ records location shall be specified by EM\&I. 
This page intentionally left blank. 


\subsection{QUALITY ASSURANCE REPORTS}

As stated in Sections 11.0 and 12.0 , Environmental Monitoring and Investigations program activities shall be assessed regularly by survelllance and auditing processes. Surveillance, nonconformance, audit, and corrective action documentation shall be considered $Q A$ records and shall be documented and dispositioned as stated in section 15.0. Records management requirements appicicable to subcontractors or participant contractors shall. be defined in applicable procurement documents or work orders as noted in section 5.3 .2 . 
This page intentionally left blank. 


\subsection{REFERENCES}

10 CFR-835, "Occupational Radiation Protection" Code of Éederal Regulations, as amended.

40 CFR 61, "National Emission standards for Hazardous Air Pollutants;" Code of Federal Regulations, as amended.

40 CFR 70, "Operating Permit Program," Code of Éderal Regulations, as amended.

40 CFR 264, "Standards for Owners and Operators of Hazarcious Waste Treatment, Storage, and Disposal Facilities," Code of Federal Regulations, as amended.

40 CER 265, "Interim Status Standards for Owners and Operators of Hazardous Waste Treatment, storage, and Disposal Facilities," Code of Federal Regulations, as amended.

40 CFR 302, "Designation, Reportable Quantities, and Notification," code of Federal Regulations, as amended.

APHA, 1985, standard Methods for the Examination of Water ard Wastewater, 16 th edition, American Public Health Association, American Water Works Association, and Water Pollution Control Eederation, Washington, D.C.

Comprehensive Environmental Response, Compensation and Liability Act of 1980 , as amended, 42 USC 9601 et seq.

Diediker, I. P. 1999, statement of Work for Service Provided by the Waste Sampling and Characterization Facility for Effluent Monitoring, HNE- EP-0835-5, Waste Management Federal Services; Hanford, Inc, , Richland, Washington.

DOE, 1981, Environmental Protection, Safety, and Health Protection Information Reporting Requirements, DOE order 5484.1,

U.S.: Department of Energy, Washington, D.C:

DOE; 1987, The Environmental Survey Manual, Appendix D, U.S. Department of Energy/Office of Environmental Audit, Washington, D.C.

DOE, 1988a, General Environmental Protection Program, DOE Order 5400.1, U.S. Department of Energy, Washington, D.C.

DOE, 1988b, Radioactive Waste Management, DOE Order 5820.2A, U.S. Department of Energy, Washington, D.C.

DOE, 1990, Radiation Protection of the Public and the Environment, DOE Order 5400.5 , U.S. Department of Energy, Washington, D.C.

DOE, 1991, Environmental Regulatory Guide for Radiological Effluent Monitoring and Environmental Surveillance, DOE/EH-0173T, U.S. Department of Energy, Washington, D.C.

DOE-RI, 1994; Radioactive Waste Management, DOE/RL-91-50, Rev. 1, U.s. Department of Energy, Richland operations office, Richland, Washington. 
EPA, 1972, Handbook for Analytical Quality Control in. Water and Wastewater Laboratories, U.S. Environmental Protection Agency, Washington, D.C.

EPA, 1977, Handbook for Analytical Quality Control in Radioanalytical Laboratories, EPA-600/7-77/088, U.S. Environmental Protection Agency, Washington, D.C.

EPA, 1979, Methods for Chemical Analysis of Water and Wastes, ERA-600/4-79-020, U.S. Environmental Protection Agency/Envixonmental. Monitoring and Support Laboratory, Cincinnati, Ohio.

EPA; 1982, Prescribed Procedures for the Measurement of Radioactivity in Drinking Water, EPA: 600/4-80-032, U.S. Environmental Protection Agency/Office of Exploratory Research; Washington; D.C.

EPA, 1983, Interim Guidelines and Specifications for Preparation of Quality Assurance Project Plans, QAMS-005/80, U.S. Environmental Protection Agency/office of Exploratory Research, Washington, D.C.

EEA, 1.984, Eastern Environmental Radiation Eacility. (EERE) Radiochemistry Procedures Manual, EPA 520/5-84-006, U.S. Environmental Protection Agency! Washington, D.C.

EPA, 1988a, Laboratory Data Validation . Functional Guidelines for Evaluating Organics Analyses, Hazardous Site Evaluation Division, U.S. Environmental Rrotection Agency, Washington, D.C.

- EPA, 1988b, Laboratory Data Validation Functional Guidelines for Evaluating Inorganics Analyses, Hazardous Site Evaluation Division, U.S. Environmental Erotection Agency, Washington, D.C.-

EPA, 1989, "USEPA Contract Iraboratory Program statement of Work for Inorganic Analysis," Federal Register, Vol. 54, No. 13, Sample - Management office, U.S. Environmental Erotection Agency, Washington, D.C.

EPA, 1992, Test Methods for Evaluating Solid Wastes, SW-846, Third Edition, U.S. Environmental Protection Agency/office of Solid Waste and Emergency Response, Washington, D.C.

HNF-MD-039, Extension of Portions of WHC-CM-4-2, Fluor Daniel Hanford, Inc;; Richland, Washington.

HNF-MP-559, Project Hanford Quality Assurance Program Description, Eluor Daniel Hanford, Ine. Richland, Washington.

HNF - PRO-52, Corrective Action Management, Fluor Daniel Hanford, Inc. Richland, Washington.

HNE-PRO-208, Records Management Control, Fluor Daniel Hanford, Inc. Richland, Washington.

HNF-PRO-246, Management Assessments, Fluor Daniel Hanford, Inc. Richland, Washington. 
HNE-PRO-268, Procurement Control, Eluor Daniel Hanford, Inc. Richland, Washington.

HNF-PRO-298, Control of Nonconforming Ițems, Fluor Daniel Hanford, Inc. Richland, Washington.

HNE-PRO-454, Inactive Waste sites, Fluor Daniel Hanford, Inc. Richland, Washington.

HNE-PRO-455, Solid Waste Management, Eluor Daniel Hanford, Inc. Richland, Washington:.

HNE-PRO-457, Environmental Requirements Evaluation, Fluor Daniel Hanford; Inc. Richland, Washington.

HNF-PRO-505, Health Physics Technical Practices and Procedures, Fluor Daniel Hanford, Inc. Richland, Wașhington.

HNE-PRO-660, General Emergency Radiological: Recovery Checklists, Fluor Daniel Hanford, Inc. Richland, Washington.

HNF-PRO-666, Grab Air Sampling, Fluor Daniel Hanford, Inc. Richland, Washington.

HNF-PRO-668, Automated Bar Coding of Air Samplers at Hanford, Fluor Daniel Hanford, Inc. Richland, Washington.

HNF-PRO-670, Radiological source Inventory, Leak Test, and Activity Determination, Fluor Daniel Hanford, Inc. Richland, Washington.

HNF-PRO-673, Performance Testing Alpha and Beta Counting Instruments, Eluor Daniel Hanford, Inc. Richland, Washington.

HNF-PRO-674, Analyzing Air and smear Samples with Alpha and Beta Counting Instruments, Fluor Daniel Hanford, Inc. Richland, Washington.

HNF-PRO-677, Release Surveys, Fluor Daniel Hanford, Inc. Richland, Washington.

HNF-PRO-678, Survey Method for Reposting Outdoor Contamination Areas, Fluor Daniel Hanford, Inc. Richland, Washington.

HNE-PRO-679, Radiological survey Reports, Fluor Daniel Hanford, Inc. Richland, Washington.

HNE-PRO-680, Radiological Material shipment and Receipt surveys, Fluor Daniel Hanford, Inc. Richland, Washington.

HNF-PRO-683, Scheduled Radiological Survey Reports, Fluor Daniel Hanford, Inc. Richland, Washington.

Thomas, S. P., 1993, Services Provided by the 222-S Laboratiory for Regulatory support, WHC-EP-0689, Westinghouse Hanford Company, Richland, washington.

WAC 173-303, 1990, "Dangerous Waste Regulations," Washington Administrative Code, as amended. 
WAC 246-247, 1990, "Radiation Pxotection Standards,". Washington Acministrative Code, as amended. :

WHC; 1991, A. Guide for Preparing Hanford Site Facility Efficient Monitoring Plans, WHC-EP-0438, Westinghouse Hanford company, Richland, Washington.

WMN-CM-004, WMNW Enviconmental Monitoring, Waste Management Federal Services, Inc. Northwest Operations, Richland, Washington.

WMNW-PCM-001, Procurement Manual, Waste Management Federal Services, Inc. Northwest operations, Richland, Washington.

WMNW-QAM-001, Quality Assurance Manual, Waste Management Federal Services, Inc. Northwest Operations, Richland, Washington.

WMNW-QAPP-001, Quality Assurance Program Plan for Project Hanford Management Contract Work, Waste Management Eedexal Services, Inc. Northwest operations, Richland, Washington. 
U.S. Department of Energy, Richland operations office
E. M. Bowers
s7 -55
R. F. Brich
K8 -50
P. F. Dunigan Jr.
A5 -15
J. B. HaII
A5-15
R. G. McLeod.
H0-12
R. o Puthoff
A7 780
H. M. Rodriguez
A. $5-15$.
D. C. Ward
A5-15
Public Reading Room
$\mathrm{H} 2-53$

Bechtel Hanford, Iric.
R. J. Iandon
$\mathrm{HO}-\mathrm{O2}$
J. G. Woolard
HO- 02
P. J. Woods
s3-20
J. E. Zoric
$\times 5-53$

Environmental Resource Center

HO -09

1

Fluor Daniel Hanford, Inc.

D. G. Ranade

H6-23

Lockheed Martin Services, Inc.

Document Erocess Center

A3-94

Central Files

Pacific Northwest National Laboratory

R. I. Dirkes

K $6-75$

R. W. Hanf

$\mathrm{K} 6-75$

Hanford Technical Iibrary

P8-55

Waste Management Fiederal Services of Hanford, Inc.
I. P. Diediker (5)
E. M. Greager

H6-36

H6-36 


\section{HNF-EP-0538-4}

Waste Management Federal Services, Inc. Northwest operations

R. K. Brockman

J. J. Dorian (2)

H1- 11

A. R. Johnson

H1-11

B. M. Markes

H1- II

S. M. MeKinney (10)

$\mathrm{H} 1-11$

J. E. Meisner

H1-1I

R. M. Mitchell

H1- 11

D. J. Moak

C. J. Perkins

H1 -11

J. M. Rodriguez

H1- 11

R. C. Roos

$\mathrm{HI}-11$

HII-11

M. R. Turner

H1-11

H1 -11 


\section{Number of copies}

ONSITE

9

U.S. Department of Energy,

Richland Operations Office

E. M. Bowers

S7 -55

R. E. Brich

K8-50

P. F. Dunigan $J x$.

A. -15

J. B. Hall

A5-15

R. G. McLeod

$\mathrm{H} 0-12$

R. O. Puthoff

A7 -80

H. M. Rodriguez

A $5-15$

D. C. Ward

A. $5-15$

Public Reading Room

Bechtel Hanford, Inc.

R. J. Landon

$\mathrm{HO}-02$

J. G. Woolard

$\mathrm{HO}-02$

P. J. Woods

S3-20

J. P. Zoric

$\times 5-53$

Environmental Resource Center

Fluor Daniel Hanford, Inc.

D. G. Ranade

H6-23

Lockheed Martin Services, Inc.

Document Process Center

A3-94

Central Files

Pacific Northwest National Laboratory

R. I. Dirkes

K6-75

R. W. Hanf

K6-75

Hanford Technical Iibrary

$\mathrm{P} 8-55$

6

Waste Management Federal Services of Hanford, Inc.

L. P. Diediker (5)

H6-36

E. M. Greager

H6-36 